\title{
TREATMENT OF PEDIATRIC FEMORAL FRACTURES IN THE CITY OF ZAGREB
}

\author{
Anko Antabak ${ }^{1}$, Nikolina Boršćak ${ }^{2}$, Marija Čagalj $^{2}$, Renato Ivelj ${ }^{3}$, Igor Bumči ${ }^{3}$, \\ Dino Papeš ${ }^{1}$, Stanko Ćavar ${ }^{1}$, Marko Bogović ${ }^{1}$, Krešimir Bulić ${ }^{1}$ and Tomislav Luetić ${ }^{1}$ \\ ${ }^{1}$ Zagreb University Hospital Centre, Department of Surgery, Division of Pediatric Surgery, Zagreb, Croatia; \\ ${ }^{2}$ University of Zagreb, School of Medicine, Zagreb, Croatia; \\ ${ }^{3}$ Zagreb Children's Hospital, Department of Surgery, Division of Traumatology, Zagreb, Croatia
}

\begin{abstract}
SUMMARY - Femur fractures in children can be treated with a number of operative and conservative methods. Numerous factors determine which method is optimal for a specific fracture. The aim of this research was to analyze distribution of femur fractures in children living in the urban communities of Zagreb and Zagreb County by localization, type and frequency of treatment methods used according to age and fracture mechanism. The research included 103 children aged up to 18 years, treated for femur fractures at the Zagreb University Hospital Centre and Zagreb Children's Hospital. Data were collected from these institutions and a retrospective study covered the 2010-2015 period. The cause of fracture and diagnosis were coded with the help of the International Statistical Classification of Diseases and Related Health Problems. Operative treatment was applied in 55\% of cases, which is contrary to previous researches. The highest incidence of femur fractures was recorded in the 0 - to 4 -year age groups, accounting for $49.1 \%$ of all fractures. These fractures mostly occurred due to falls and were more often treated with non-operative methods. All other age groups were mostly treated with operative methods. Coxofemoral immobilization and traction were used as non-operative methods, whereas flexible intramedullary nailing was the most frequently used operative method. The treatment depended on age, complexity of the fracture, fracture type, fragment displacement, and associated injuries. The cause was also an important factor on choosing the treatment method. Nonoperative treatment was mostly used for fractures caused by falls $(64.71 \%$ of cases due to falls) and operative treatment was mostly used for fractures caused by traffic accidents $(79.4 \%$ of cases due to traffic accidents). It is a wide-known opinion that the best treatment for femur fractures in children is non-operative treatment. However, recent studies have shown that the use of operative methods in femur fracture treatment is growing. Our cohort of children treated during a five-year period (20102015) also underwent operative treatment more often than non-operative one. Two non-operative and eight operative methods were used. With such a large number of methods, it is clear that there is no unique method for all fractures. However, it is clear that the trend of using operative treatment is connected to the perennial trend of considerable sociodemographic and socioeconomic changes in urban settings such as Zagreb. Lifestyle changes directly affect the prevalence of femur fractures among children, as well as approach to treatment choice. General opinion is that most of fractures that occur at an early age can be treated with non-operative methods. Our research on femur fractures in children confirmed this rule. The youngest age group that had the highest incidence of fractures ( $49.1 \%$ of all fractures) was treated with non-operative methods in $75 \%$ of cases. Operative methods prevailed in other age groups. Similar results have been published by other authors. In conclusion, nearly half of all
\end{abstract}

Correspondence to: Prof. Anko Antabak, MD, PhD, Department of Surgery, Zagreb University Hospital Centre, Kišpatićeva 12, HR-10000

Zagreb, Croatia

E-mail: aantabak@kbc-zagreb.hr

Received December 19, 2016, accepted October 29, 2018 
femur fractures (49.1\%) occurred at a young age (0-4 years). Diaphysis fractures were most common. Most of the fractures that occurred during the 2010-2015 period were treated with operative methods, mostly in children aged 5-9 years. Out of eight different operative methods, elastic stable intramedullary osteosynthesis was most frequently used (60\%). Coxofemoral immobilization and traction were used as non-operative methods.

Key words: Femur; Fracture; Child; Treatment

\section{Introduction}

Fractures are common injuries in children ${ }^{1}$. Femur fractures make up to $7 \%$ of all fractures in children ${ }^{2}$. Femur is the strongest bone in human body. Its fracture is a severe injury complicated by the length of treatment procedure and uncertainty of its outcome. Numerous complications are connected to femur fractures in children. The fractures occur by the influence of high energy forces, and are often accompanied by fragment displacement. Femur instability is caused by the loss of the femur supportive function due to disruption of the complex biomechanical balance of forces in the thigh musculature (22 muscles). Their realignment is difficult, and retention is often possible only after fixing bone fragments ${ }^{3}$. Consequently, most of the children with femur fractures require urgent hospitalization ${ }^{4,5}$. Most of the femur axial growth (70\%) occurs in the distal epiphyseal plate, and if injured it can cause severe growth restriction and deformities ${ }^{6}$. However, accelerated axial growth of the femur after metaphyseal fractures is also possible ${ }^{7}$. The proximal part of the femur has an especially adverse vascularization, which can cause avascular necrosis of the femur head and consequently a severe outcome ${ }^{8,9}$. Spontaneous corrections of frontal angular deformities in diaphyseal fractures, especially in older children, are often insufficient ${ }^{10}$. These facts demonstrate that femur fractures in children carry a high risk of potential poor outcomes. High biological healing potential with endosteal and, typical for children, periosteal callus ensures rapid healing and brief resting. Minor angular deformities of the fractured fragments can be corrected by the activity of the epiphyseal growth plates and the periosteal germinative layer in the process of reconstruction and axial growth. Hence, ideal reposition is not always necessary ${ }^{11}$. However, this advantage is less expressed in older children. Considering the traps and conveniences linked to femur fractures in children, it is no surprise that there is no unique opinion about what the optimal method for a particular fracture or a particular age is ${ }^{12-14}$.
The principle of fracture treatment is to secure an appropriate fragment position (reposition) and to stabilize the fragments (securing fragment inaction) during bone healing. Treatment is conducted with operative and non-operative procedures. Reposition can be closed (manual) and open. Fragment stabilization can be accomplished with operative procedures (intramedullary or extramedullary osteosynthesis), non-operative procedures (cast immobilization of two neighboring joints), or with traction methods. The most common non-operative procedures imply closed reposition and fragment stabilization by cast immobilization ${ }^{15}$, Pavlik harness, or skin traction ${ }^{16,17}$. Operative methods are open or closed fragment reposition with the help of intramedullary fixation, or another form of operative fragment fixation. The most widely used method is closed reposition with intramedullary osteosynthesis under roentgen diascopy during general anesthesia. Operative methods include external fixation ${ }^{18,19}$, plates $^{20}$, screws ${ }^{21}$, flexible ${ }^{22}$ or rigid intramedullary osteosynthesis, and Kirschner wires ${ }^{24}$. Each of them has its own advantages, but also disadvantages ${ }^{25-28}$. Hospital-based treatment with the use of surgical methods is directed to brief hospital stay, quick recovery, and a satisfactory outcome without complications. On the contrary, conservative treatment does not carry the risks of operative complications, but it lasts longer and is followed by the negative effect of restricting daily activities. This kind of psychological and social effect of hospitalization does not only affect children, but also their parents. In some cases of femur fracture, there is no doubt about the choice of the optimal treatment method (birth-related fractures). However, in most cases it is not that simple to choose an optimal $\operatorname{method}^{29,30}$. The choice of optimal procedure is not based only on the surgeon's opinion. It has to be adjusted to equipment capacity, accessibility to materials and instruments, expertise and experience of the medical team, opinion of the medical sector board, and especially the parent's stand ${ }^{31}$. Parents often expect rapid and complete recovery after the fracture, without com- 

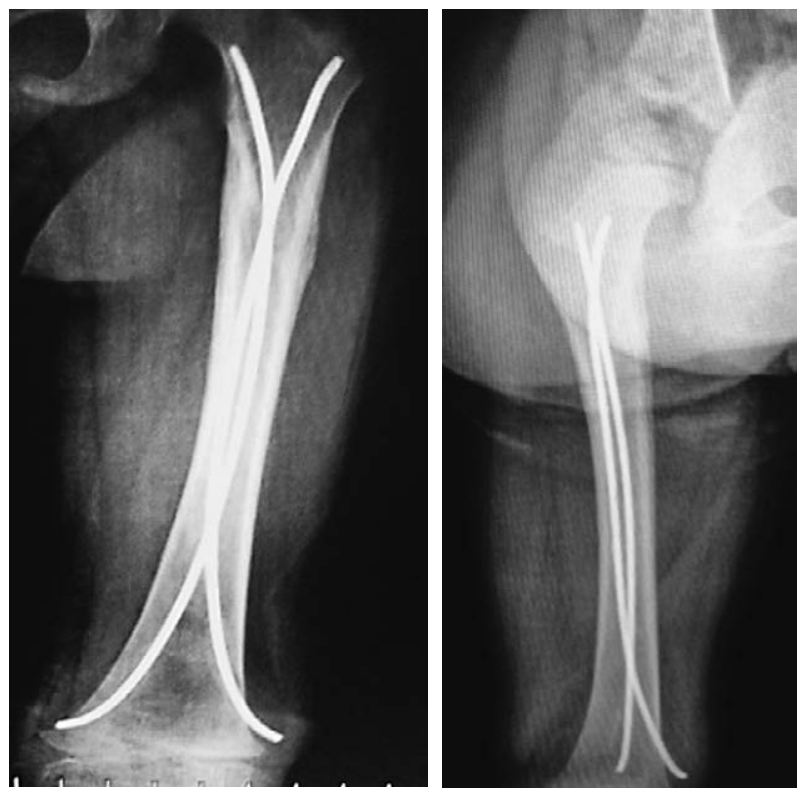

Fig. 1. Proximal femur fracture in a 5-year-old boy treated with placement of flexible intramedullary wires: $x$-ray performed three weeks after the operation shows an accurate position of osteosynthetic materials with abundant periosteal callus formation at the fracture site.

plications. The procedure is primarily determined by medical criteria linked to patient age, weight, type of injury, degree of fragment displacement, time elapsed from the occurrence of the injury to its sanitation, and comorbidities. Complete fractures without fragment displacement, subperiosteal fractures, and greenstick fractures with minimal displacement can be treated with immobilization only, and therefore hospitalbased treatment is not necessary ${ }^{32}$. Femur fractures often require fragment reposition and hospitalization. This kind of hospital-based treatment has to be adjusted to the child's age and fracture type ${ }^{33}$. There are some traditional stands on treatment choice depending on age ${ }^{34}$. Thereby, children aged up to five years undergo non-operative treatment, while children over the age of twelve undergo rigid intramedullary osteosynthesis $^{31}$. There is no solid consensus on the ideal procedure for children aged between five and twelve years, and therefore various methods are used ${ }^{35}$. An overview of recent literature indicates that treatment approach has been changing during the last twenty years. Procedures that shorten treatment duration, especially hospitalization, are used more frequently. Sports habits and children's lifestyles change the oc-
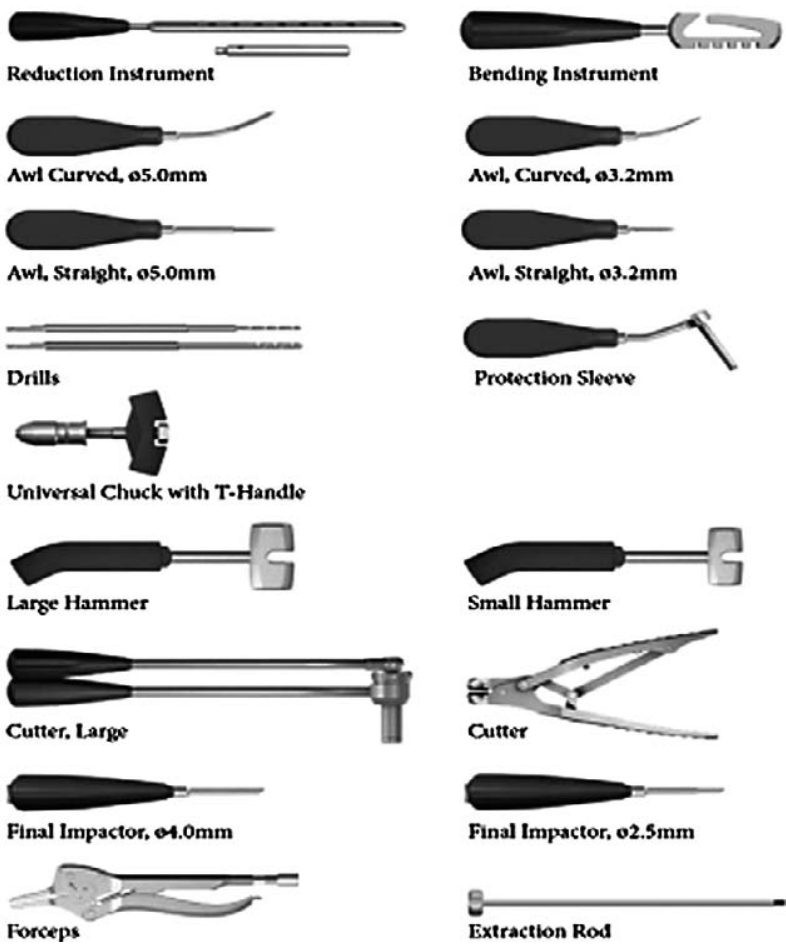

Fig. 2. Surgical set for operative treatment of femur fractures with the stable intramedullary osteosynthesis method.

currence, methods and locations of femur fractures. Technological development of new materials and instruments for osteosynthesis, and the need for shortening hospital-based treatment and rapid return to everyday activities are all in favor of operative approach for treating femur fractures in children. Therefore, certain non-operative methods in younger children have been replaced by operative fragment fixation ${ }^{36}$. There has been a number of good reports in recent years on the results obtained by the elastic stable intramedullary nailing (ESIN) method using flexible wires made of titanium alloys (Fig. 1) ${ }^{40-42}$. The most recent technological adjustment of this method are wires made of ionized titanium and chromium alloys. The new, more adamant and elastic wire with a smaller diameter can, with the use of appropriate instruments (Fig. 2), open up a whole new spectrum of treatment possibilities for femur fractures in older and heavier children. The use of this method has very few restrictions, therefore it can be used in almost every age group. However, there are some authors claiming this method to be overly and uncontrollably used ${ }^{43-45}$. 
Table 1. Treatment methods for femur fractures in children aged $\leq 18$ years

\begin{tabular}{|l|l|l|l|}
\hline $\begin{array}{l}\text { Treatment } \\
\text { method }\end{array}$ & $\begin{array}{l}\text { Fractures } \\
\mathrm{n}\end{array}$ & $\%$ \\
\hline Non-operative & $\begin{array}{l}\text { Traction and } \\
\text { coxofemoral } \\
\text { immobilization }\end{array}$ & 28 & 26.5 \\
\cline { 2 - 4 } & $\begin{array}{l}\text { Coxofemoral } \\
\text { immobilization }\end{array}$ & 20 & 18.9 \\
\hline \multirow{5}{*}{ Operative } & ESIN & 34 & 32.4 \\
\cline { 2 - 4 } & Kirschner wires & 5 & 4.9 \\
\cline { 2 - 4 } & Plates and screws & 4 & 3.9 \\
\cline { 2 - 4 } & External fixator & 4 & 3.9 \\
\cline { 2 - 4 } & Tubular screws & 3 & 2.8 \\
\cline { 2 - 4 } & $\begin{array}{l}\text { Osteosynthesis by } \\
\text { tension-band wiring }\end{array}$ & 3 & 2.9 \\
\cline { 2 - 4 } & $\begin{array}{l}\text { Rigid } \\
\text { intramedullary nail }\end{array}$ & 2 & 1.9 \\
\cline { 2 - 4 } & Kuntscher nail & 2 & 1.9 \\
\hline Total & & 106 & 100 \\
\hline
\end{tabular}

ESIN = elastic stable intramedullary nailing

This study analyzed the occurrence of femur fractures in children living in urban communities (Zagreb and Zagreb County) by localization and type, and the frequency of methods used in treating these fractures according to age groups. The study was conducted in two hospitals that possess contemporary equipment (instruments), as well as educated staff for performing all treatment procedures in children with femur fractures. The Excel 2007 computer program was used on statistical analysis.

The aim of this research was to analyze the distribution of femur fractures in children living in the urban communities of Zagreb and Zagreb County by localization and type, and the frequency of treatment methods used according to patient age and fracture mechanism.

\section{Subjects and Methods}

This retrospective study included 106 femur fractures in 103 children up to 18 years of age treated for femur fractures at the Zagreb University Hospital Centre and Zagreb Children's Hospital during the 2010-2015 period. All study children were citizens of the City of Zagreb or Zagreb County. Data were obtained from the hospital information system and archived medical documentation. Birth-related fractures, fractures caused by self-harm or abuse, pathological fractures and fractures with incomplete medical documentation were excluded from the study. During the study, patient data were collected in a Microsoft Excel table. The following data were collected and analyzed: year, month and day of the incident, age and sex of the child, diagnosis coded with the help of the International Classification of Diseases (ICD)-10, associated injuries, what leg was affected, what part of the femur was fractured, whether the fracture was open or closed, x-ray findings, fragment displacement, fracture complexity, fracture completeness, location where the injury occurred, mechanisms of the injury coded with the help of ICD-10, non-operative or operative treatment, duration of non-operative treatment, and the method used for operative treatment. Statistical analysis was performed by use of Microsoft Excel.

\section{Results}

Out of 106 fractures, 48 (45\%) were treated with non-operative methods and 58 (55\%) with operative methods. Coxofemoral immobilization was used as non-operative treatment alone or combined with traction (first traction, then coxofemoral immobilization) (Table 1). Non-operative treatment was conducted for at least two weeks, eight weeks at most. Elastic stable intramedullary osteosynthesis was used in 34 fractures, which made $60 \%$ of all operative procedures. The remaining $40 \%$ were seven techniques of fragment fixation in femur fractures. Considering age, 52 fractures (49.1\% of all fractures) occurred in children aged 0-4 years (Fig. 3). Most of them (75\%) were treated without the need for surgical intervention. Of the 106 fractures analyzed, 21 (19.8\%) children were aged 5-9 years. Most of them (90.5\%) were treated with operative methods. The 10-13 age group included 19 children, of which $84.2 \%$ were treated with operative methods. The oldest age group (14 to 18 years) included 14 children, of which $71.4 \%$ were treated with operative methods.

Femur fractures were divided into fractures of the proximal, middle and distal part. Fractures of the middle part occurred in 66 (62.3\%) children, of which 40 


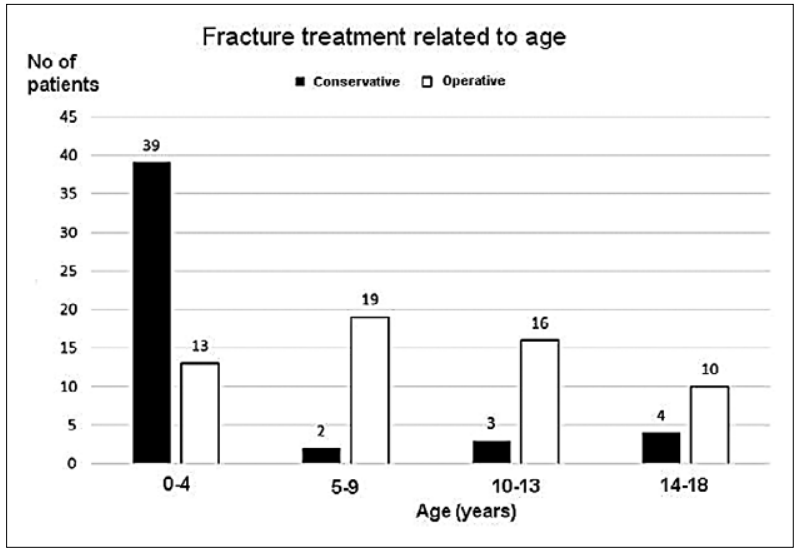

Fig. 3. Comparison of treatment methods according to age groups.

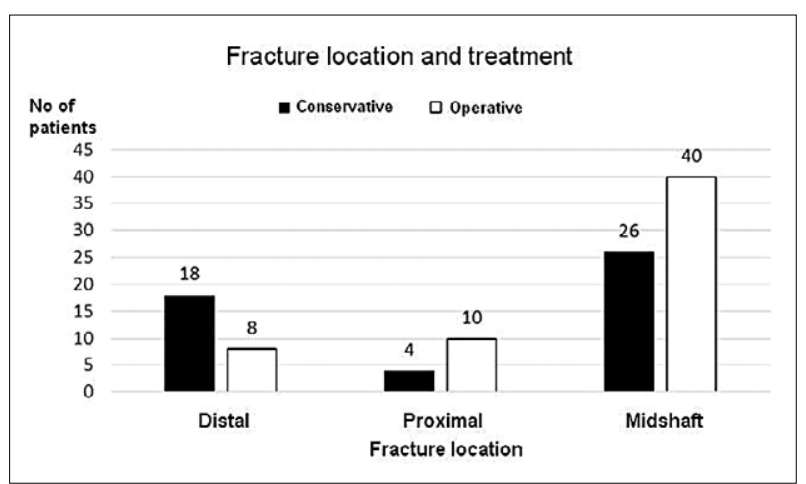

Fig. 4. Comparison of treatment methods according to fracture localization.

$(60.6 \%)$ were treated with operative methods. Fractures of the distal part occurred in $26(24.5 \%)$ children, of which $18(69.2 \%)$ were treated with non-operative methods. Fractures of the proximal part occurred in 14 (13.2\%) children, of which ten (71.4\%) were treated with operative methods (Fig. 4). Out of 100 complete fractures, 56 were treated with operative methods. The status of complete fracture remained unknown in two cases and both were treated with operative methods. There were four incomplete fractures, all of them treated with non-operative methods. There were five open fractures, all of them treated with operative methods. Closed fractures occurred in 100 cases, of which 52 were treated with operative methods. In one case, it was unknown whether the fracture was open or closed, and it was treated with operative method. Complex fractures occurred in 34 children and 28 of them were treated with operative methods. There were 72 simple fractures, of which 44 were treated with non-operative methods. Associated injuries were treatment obstacles in 40 cases, including superficial injuries, other fractures that included fractures of other lower extremity bones, upper extremity bones, ribs, spine bones, pelvic bones, and skull bones, concussion, open wounds, and contusions of abdominal organs. Four children were diagnosed with multiple traumas. Out of 40 children that had femur fractures with associated injuries, 30 were treated with operative methods and ten with non-operative methods. Isolated fractures occurred in 66 children, of which 28 and 38 were treated with operative and non-operative methods, respectively. There were multiple causes of femur fractures in children. In our cohort of children, falls and traffic accidents were the most common causes. Traffic related injuries were treated with operative methods in $79.4 \%$ of cases. Fractures caused by falls on the same level due to slipping, tripping and stumbling, falls involving ice-skates, skis, roller-skates or skateboards, falls involving beds, falls on and from stairs and steps, falls from, out of or through buildings or structures, falls from one level to another, and by striking against or getting struck by other objects happened in 51 cases, of which $64.71 \%$ were treated with non-operative methods. Fractures by falls on the same level due to collision with or pushing by another person, falls involving furniture, and by striking against or bumped into by another person happened in six cases, and all of them were treated with non-operative methods. Fractures by falls while being carried or supported by other persons, falls involving a chair, falls involving playground equipment, and falls from trees happened in one case each, and all of them were treated with operative methods. Fractures by striking against or being struck by sports equipment, and by getting caught, crushed, jammed or pinched in or between objects occurred in two cases each, and all of them were treated with operative methods. Fractures by unspecified falls were equally treated with operative and non-operative methods.

\section{Discussion}

It is a wide-known opinion that the best treatment for femur fractures in children is non-operative treatment ${ }^{46}$. However, recent studies have shown that the use of operative methods in femur fracture treatment is growing ${ }^{35,36,47}$. Our cohort of children treated during 
a five-year period (2010-2015) also underwent operative treatment more often than non-operative one. During the study period, two non-operative and eight operative methods were used. With such a large number of methods, it is clear that there is no unique method for all fractures. We did not investigate whether the methods used were justified since even larger studies, such as the one conducted by Madhuri et al. (532 children) failed to find enough evidence for advantages of operative over non-operative methods ${ }^{38}$. Now it is clear that the trend of using operative treatment is connected to the perennial trend of considerable sociodemographic and socioeconomic changes in urban societies such as Zagreb. Lifestyle changes directly affect the prevalence of femur fractures among children, and also the approach to treatment choice ${ }^{48}$. Heideken et al. showed a 20-year decreasing trend in the prevalence of femur fracture (about three percent annually) in Swedish children ${ }^{49}$. The highest prevalence of femur fractures is in the 4-12 age group. In our cohort of children, the highest prevalence was recorded in the age group of 0-4 years with $20.4 \%$ of all femur fractures analyzed. In Croatia, there are no public health studies considering the prevalence of bone fractures in children, or any professional studies to monitor them, as compared to the study by Naranje et al. which analyzed 74,483 femur fractures in American children during a 15 -year interval ${ }^{37}$. In all age groups, the prevalence of fractures was by $25 \%$ lower in 2012 than in 1997. However, the number of operated children older than 5 years increased, especially in the 5-9 age group (twice as often in 2012 than in 1997) ${ }^{37}$. We operated on children at that age (5-9 years of age) and also, at a lower percentage, the children from older age groups. Diaphysis fractures were the most common fractures according to localization and they were more often treated with operative than non-operative methods. Fractures of the proximal part were rarest, and they were mostly treated with operative methods (71\%). The non-operative method most often used in Zagreb children was coxofemoral immobilization, with or less frequently without previous skin traction. This method has a relatively high percentage of fragment shortening by two or more centimeters. Shortenings greater than two centimeters occur in up to $43 \%$ of children if skin traction was not used before immobilization and in $18 \%$ of children if traction was used for two weeks before immobilization ${ }^{37}$. Recent studies on femur frac- tures in children show that authors prefer procedures that shorten treatment period, especially hospital stay $^{37,39,40,45}$. Intramedullary osteosynthesis is by far the most widely used method to achieve it. It ensures rapid healing, low rate of complications, and short hospital stay ${ }^{50,51}$. Kuntscher nail was used previously, but its use has been almost abandoned with better understanding of the vascularization of the femur proximal part. The last ten years have brought changes in the insertion methodology, and therefore new fixation techniques $^{51,52}$. Fixation method choice depends on the fracture type, patient age, skeletal maturity and body mass index. Flexible intramedullary fixation with titanium elastic nailing was the operative method most frequently used ( $60 \%$ of operated children) in treating our cohort of children. There are numerous studies on this treatment method. Our authors also have published their experiences with this treatment method ${ }^{53}$. The majority of authors agree that it is the optimal stabilization method for most of femur fractures in children older than 13 years and body mass up to 55 kilograms $s^{54}$. However, there are some that prefer this method also in older ${ }^{55}$ and heavier children (up to 85 kilograms $)^{56}$. The market offers many models of osteosynthetic materials (implants) of similar biomechanical characteristics that are used for this method. They are made of medical steel of an extremely high purity level (class $316 \mathrm{LVM}$ ), or titanium alloys with aluminum, niobium or vanadium $(\mathrm{Ti}-6 \mathrm{Al}-7 \mathrm{Nb}, \mathrm{Ti}-6 \mathrm{Al}-$ $4 \mathrm{~V})$, with diameters from 1.5 to 4 millimeters. Titanium and steel nails differ in strength and elasticity. The newest models of titanium elastic factory made convex curved wires (manufactured by Stryker ${ }^{\circledR}$ ) have been described in the first appearing articles analyzing their advantages and disadvantages in 100 children treated with this method ${ }^{45}$. Our cohort of children were treated by fragment fixation with Kirschner wires in $9 \%$ of all fractures treated with operative methods. The authors of studies that compared this method to titanium elastic nails claim that there is no difference between them in treating femur fractures in the 5-12 age group ${ }^{24,57}$. Ender nail is still used in some cases, but it was not used in this study. The authors of this study have experience with this method, and it has been abandoned. The study conducted by Balakumar and Natarajan comparing treatment results in 15 children aged 5-12 years showed significantly better results in children treated with $\mathrm{ESIN}^{58}$. Plates and screws were 
used in $7 \%$ of all fractures treated with operative methods. The authors that often use this method report on the ESIN method to be advantageous in treating children older than six years, with weight limited to 45 kilograms ${ }^{59}$. We used the external fixator stabilization method in three children. External fixator in children with femur fractures carries a complication rate of $6 \%$, but it is appropriate for children with multifragmentary and unstable fractures when ESIN is unsuitable, especially in adolescents with high energy fractures ${ }^{4,60}$.

General opinion is that most of the fractures that occur at an early age can be treated with non-operative methods ${ }^{61}$. Our research on femur fractures in children confirmed this rule. The youngest age group that had the highest incidence of fractures (49\% of all fractures) were treated with non-operative methods in $75 \%$ of cases. Operative methods prevailed in other age groups. Similar results have been published by other authors ${ }^{4,62}$.

\section{Conclusion}

Nearly half of all femur fractures (49.1\%) occurred at a young age (0-4 years). Diaphysis fractures were most common. Most of the fractures that occurred during the 2010-2015 period were treated with operative methods, mostly in children aged 5 to 9 years. Out of eight different operative methods, ESIN was most frequently used (60\%). Coxofemoral immobilization and traction were used as non-operative methods.

\section{References}

1. Hedström EM, Svensson O, Bergström U, Michno P. Epidemiology of fractures in children and adolescents. Increased incidence over the past decade: a population-based study from northern Sweden. Acta Orthop. 2010;81:148-53. https://doi. org/10.3109/17453671003628780

2. Smailji M, Maričić A, Kvesić A, Martinović V. Incidencija prijeloma kostiju lokomotornog aparata u djece i adolescenata. Medicina. 2009;45:358-68. (in Croatian)

3. Bottlang M, Schemitsch CE, Nauth A, Routt M Jr, Egol KA, Cook GE. Biomechanical concepts for fracture fixation. J Orthop Trauma. 2015;29 Suppl 12:28-33. https://doi.org/ 10.1097/BOT.0000000000000467

4. Kocher MS, Sink EL, Blasier RD, Luhmann SJ, Mehlman CT, Scher DM, et al. American Academy of Orthopaedic Surgeons Clinical Practice Guideline on Treatment of Pediatric Diaphyseal Femur Fracture. J Bone Joint Surg Am. 2010;92:1790-2. https://doi.org/ 10.2106/JBJS.J.00137
5. Heideken von J, Svensson T, Iversen M, Ekbom A, Janarv PM. Femur shaft fracture at a young age and the risk of subsequent severe injuries during childhood: a cohort study. BMC Pediatr. 2014;14:62. https://doi.org/ 10.1186/1471-2431-14-62

6. Bassett WP, Safier S, Herman MJ, Kozin SH, Abzug JM. Complications of pediatric femoral shaft and distal physeal fractures. Instr Course Lect. 2015;64:461-70.

7. Stilli S, Magnani M, Lampasi M, Antonioli D, Bettuzzi C, Donzelli O. Remodelling and overgrowth after conservative treatment for femoral and tibial shaft fractures in children. Chir Organi Mov. 2008 Jan;91(1):13-9.

8. Mirdad T. Paediatric hip fractures: a systematic review of incidence, treatment options and complications. Acta Orthop Belg. 2010 Feb;76(1):7-13.

9. Song KS. Displaced fracture of the femoral neck in children: open versus closed reduction. J Bone Joint Surg Br. 2010 Aug;92(8):1148-51. https://doi.org/ 10.1302/0301-620X.92 B8.24482

10. von Laer L. Pediatric Fractures and Dislocations. Stuttgart: Thieme, 2004.

11. Strohm PC, Schmittenbecher PP. Femoral shaft fractures in children under 3 years old. Current treatment standard. Unfallchirurg. 2015;118:48-52. https://doi.org/ 10.1007/s00113014-2639-7

12. Flynn JM, Curatolo E. Pediatric femoral shaft fractures: a system for decision making. Instr Course Lect. 2015;64:453-60.

13. Kosuge D, Barry M. Changing trends in the management of children's fractures. Bone Joint J. 2015;97-B(4):442-8. https:// doi.org/ 10.1302/0301-620X.97B4.34723

14. von Laer L. Growth behavior after epiphyseal plate injury: importance of "watertight" osteosynthesis. Unfallchirurg. 2014; 117(12):1071-84. https://doi.org/ 10.1007/s00113-014-2631-2

15. Akinyoola AL, Orekha OO, Taiwo FO, Odunsi AO. Outcome of non-operative management of femoral shaft fractures in children. Afr J Paediatr Surg. 2011;8(1):34-9. https://doi.org/ 10.4103/0189-6725.78666

16. Esenyel CZ, Oztürk K, Adanir O, Aksoy B, Esenyel M, Kara AN. Skin traction in hip spica casting for femoral fractures in children. J Orthop Sci. 2007 Jul;12(4):327-33. https://doi.org/ 10.1007/s00776-007-1148-8

17. Wang CN, Chen JJ, Zhou JF, Tang HB, Feng YB, Yi X. Femoral fractures in infants: a comparison of Bryant traction and modified Pavlik harness. Acta Orthop Belg. 2014;80:63-8.

18. Eichinger JK, McKenzie CS, Devine JG. Evaluation of pediatric lower extremity fractures managed with external fixation: outcomes in a deployed environment. Am J Orthop. 2012; 41(1):15-9.

19. Wani MM, Dar RA, Latoo IA, Malik T, Sultan A, Halwai MA. External fixation of pediatric femoral shaft fractures: a consecutive study based on 45 fractures. J Pediatr Orthop B. 2013;22 (6):563-70. https://doi.org/ 10.1097/BPB.0b013e32836421ce

20. Abdelgawad AA, Sieg RN, Laughlin MD, Shunia J, Kanlic EM. Submuscular bridge plating for complex pediatric femur 
fractures is reliable. Clin Orthop Relat Res. 2013;47:2797-807. https://doi.org/ 10.2106/JBJS.ST.15.00059

21. Tsang KS, Adedapo A. Cannulated screw fixation of fracture neck of femur in children with osteogenesis imperfecta. J Pediatr Orthop B. 2011;20(5):287-90. https://doi.org/ 10.1097/ BPB.0b013e328347a345

22. Sun LJ, Yang J, Tian NF, Wu YS, Yu XB, Hu W, Guo XS, Chen H. Pediatric femoral shaft fractures treated with titanium elastic nailing. Orthopedics. 2014;37:1021-6. https://doi.org/ 10.12669/pjms.346.16297

23. Elgohary HS, El Adl WA. Antegrade rigid nailing through the tip of the greater trochanter for pediatric femoral shaft fractures. Eur J Orthop Surg Traumatol. 2014;24(7):1229-35. https://doi.org/ 10.1007/s00590-013-1382-z

24. Goyal N, Aggarwal AN, Mishra P, Jain A. Randomized controlled trial comparing stabilization of fresh close femoral shaft fractures in children with titanium elastic nail system versus stainless steel elastic nail system. Acta Orthop Belg. 2014; 80(1):69-75.

25. Shemshaki HR, Mousavi H, Salehi G, Eshaghi MA. Titanium elastic nailing versus hip spica cast in treatment of femoralshaft fractures in children. J Orthop Traumatol. 2011;12(1): 45-8. https://doi.org/ 10.1007/s10195-011-0128-0

26. Sagan ML, Datta JC, Olney BW, Lansford TJ, McIff TE. Residual deformity after treatment of pediatric femur fractures with flexible titanium nails. J Pediatr Orthop. 2010;30(7): 638-43. https://doi.org/ 10.1097/BPO.0b013e3181efb8e2

27. Frech-Dörfler M, Hasler CC, Häcker FM. Immediate hip spica for unstable femoral shaft fractures in preschool children: still an efficient and effective option. Eur J Pediatr Surg. 2010;20(1):18-23. https://doi.org/ 10.1055/s-0029-1241177

28. Saseendar S, Menon J, Patro DK. Treatment of femoral fractures in children: is titanium elastic nailing an improvement over hip spica casting? J Child Orthopaed. 2010;4(3):245-51. https://doi.org/ 10.1007/s11832-010-0252-z

29. Guled U, Kumar V, Saibaba B, Kishan R. Management protocol for shaft femur fractures in preschool-age children: do we need to rethink? J Pediatr Orthop. 2016;36:39. https://doi.org/ 10.1016/j.jcot.2016.12.004

30. Kosuge D, Barry M. Changing trends in the management of children's fractures. Bone Joint J. 2015;97-B(4):442-8. https:// doi.org/ 10.1302/0301-620X.97B4.34723

31. Heyworth BE, Suppan CA, Kramer DE, Yen YM. Management of pediatric diaphyseal femur fractures. Curr Rev Musculoskelet Med. 2012 Jun;5(2):120-5. https://doi.org/ 10.1007/ s12178-012-9112-4

32. Rapp M, Kaiser MM, Grauel F, Gielok C, Illing P. Femoral shaft fractures in young children $(<5$ years of age): operative and non-operative treatments in clinical practice. Eur J Trauma Emerg Surg. 2015;3:96. https://doi.org/ 10.1007/s00068-0150570-4

33. Scheerder FJ, Schnater JM, Sleeboom C, Aronson DC. Bryant traction in paediatric femoral shaft fractures, home traction versus hospitalisation. Injury. 2008;39(4):456-62. https://doi. org/ 10.1016/j.injury.2007.07.029

34. Melisie F, Krug E, Duijff JW, Krijnen P, Schipper IB. Agespecific treatment of femoral shaft fractures in children. Ned Tijdschr Geneeskd. 2012;156:3976.

35. Flynn JM, Skaggs DL, Peter M. Waters. In: Rockwood \& Wilkins' Fractures in Children. Philadelphia: Wolters Kluwer, 2015.

36. Jain A, Aggarwal A, Gulati D, Singh MP. Controversies in orthopaedic trauma management of fractures of shaft of femur in children between 6 and 12 years of age. Kathmandu Univ Med J (KUMJ). 2014;12:77-84.

37. Naranje SM, Stewart MG, Kelly DM, Jones TL, Spence DD, Warner WC Jr, Beaty JH, Sawyer JR. Changes in the treatment of pediatric femoral fractures: 15-year trends from United States Kids' Inpatient Database 1997 to 2012. J Pediatr Orthop. 2016;36(7):81-5. https://doi.org/ 10.1097/bpo.00000000000 00633

38. Madhuri V, Dutt V, Gahukamble AD, Tharyan P.Interventions for treating femoral shaft fractures in children and adolescents. Evid Based Child Health. 2014;9:753-826. https://doi.org/ 10.1002/14651858.CD009076.pub2

39. Guimarães JA, Mendes PH, Vallim FC, Rocha LR, Rocha TH, do Val IC, Duarte ME. Surgical treatment for unstable pelvic fractures in skeletally immature patients. Injury. 2014;45 Suppl 5:40-5. https://doi.org/ 10.1016/S0020-1383(14)70020-8

40. Knedel M, Gallego EW, Gerardi J, Husak L, Altebarmakian M.Preliminary report: pediatric femur fractures: single incision intramedullary stabilization technique. J Pediatr Orthop. 2015;35(7):657-60. https://doi.org/ 10.1097/bpo.0000000000 000369

41. Khan JA, Singh GP, Pandey A. Outcome of titanium elastic intramedullary nail in the treatment of shaft of femur fracture in children. Kathmandu Univ Med J. 2015;13:195-9. https:// doi.org/ 10.1097/ 10.3126/kumj.v13i3.16799

42. Ramo BA, Martus JE, Tareen N, Hooe BS, Snoddy MC, Jo $\mathrm{CH}$. Intramedullary nailing compared with spica casts for isolated femoral fractures in four- and five-year-old children. J Bone Joint Surg Am. 2016;98(4):267-75. https://doi.org/ 10.2106/JBJS.O.00706

43. Karaman I, Halici M, Kafadar IH, Guney A, Oner M, Gurbuz $\mathrm{K}$, Karaman ZF. Mid-term results of the elastic intramedullary nailing in paediatric long bone shaft fractures: a prospective study of 102 cases. J Pediatr Orthop B. 2014;23(3):212-20. https://doi.org/ 10.1097/01.bpb.0000444460.95927.05

44. Salonen A, Lahdes-Vasama T, Mattila VM, Välipakka J, Pajulo O. Pitfalls of femoral titanium elastic nailing. Scand J Surg. 2015;104(2):121-6. https://doi.org/ 10.1177/145749691452 9275

45. Lascombes P, Nespola A, Poircuitte JM, Popkov D, Gheldere A, Haumont T, Journeau P. Early complications with flexible intramedullary nailing in childhood fracture: 100 cases managed with precurved tip and shaft nails. Orthop Traumatol Surg Res. 2012;98(4):369-75. https://doi.org/ 10.1016/j. otsr.2011.11.011 
46. Guo YC, Feng GM, Xing GW, Yin JN, Xia B, Dong YZ, Niu $\mathrm{XQ}_{2} \mathrm{He} \mathrm{Q}_{2} \mathrm{Hu}$ P.A meta-analysis of flexible intramedullary nailing versus external fixation for pediatric femoral shaft fractures. J Pediatr Orthop B. 2016;25(5):466-70. https://doi.org/ 10.1097/BPB.0000000000000336

47. Flynn JM, ed. Rockwood and Wilkins' Fractures in Children. Philadelphia: Wolters Kluwer, 2014.

48. Lieber J, Schmittenbecher P. Developments in the treatment of pediatric long bone shaft fractures. Eur J Pediatr Surg. 2013;23:427-33. https://doi.org/ 10.1055/s-0033-1360460

49. Heideken J, Svensson T, Blomqvist P, Haglund-Akerlind Y, Janarv P. Incidence and trends in femur shaft fractures in Swedish children between 1987 and 2005. J Pediatr Orthop. 2011;31:512-9. https://doi.org/ 10.1097/BPO.0b013e31821 f9027

50. Lee YH, Lim KB, Gao GX, Mahadev A, Lam KS, Tan SB, Lee EH. Traction and spica casting for closed femoral shaft fractures in children. J Orthop Surg (Hong Kong). 2007;15:37-40. https://doi.org/ 10.1177/230949900701500109

51. Bandyopadhyay, R, Mukherjee A. Short term complications of titanium elastic nail in the treatment of diaphyseal fracture of the femur in children. Open Orthop J. 2013;7:12-7.

52. Sink L, Faro F, Polousky J, Flynn K, Gralla J. Decreased complications of pediatric femur fractures with a change in management. J Pediatr Orthopaed. 2010;7:633-7. https://doi.org/ 10.1097/BPO.0b013e3181efb89d

53. Furlan D, Pogorelić Z, Biočić M, Jurić I, Budimir D, Todorić J, Šušnjar T, Todorić D, Meštrović J. Elastic stable intramedullary nailing for pediatric long bone fractures: experience with 175 fractures. Scand J Surg. 2011;100:208-15. https://doi.org/ 10.1177/145749691110000313

54. Hosalkar HS1, Pandya NK, Cho RH, Glaser DA, Moor MA, Herman MJ. Intramedullary nailing of pediatric femoral shaft fracture. J Am Acad Orthop Surg. 2011;19:472-81. https://doi. org/ 10.5435/00124635-201108000-00003
55. Canavese F, Marengo L, Andreacchio A, et al. Complications of elastic stable intramedullary nailing of femoral shaft fractures in children weighing fiftykilograms (one hundred and ten pounds) and more. Int Orthop. 2016;40:2627-34 https://doi. org/ 10.1007/s00264-016-3259-3

56. Parikh SN, Jain VV, Denning J, et al. Complications of elastic stable intramedullary nailing in pediatric fracture management: AAOS exhibit selection.J Bone Joint Surg Am. 2012;19;94:184. https://doi.org/ 10.1097/00004694-200407000-00004

57. Gyaneshwar T, Nitesh R, Sagar T, Pranav K, Rustagi N. Treatment of pediatric femoral shaft fractures by stainless steel and titanium elastic nail system: a randomized comparative trial. Chin J Traumatol. 2016;19:213-6. https://doi.org/ 10.1016/j. cjtee.2016.02.001

58. Balakumar B, Natarajan MV. Is there a role for Ender's nailing of paediatric femoral fractures in a resource-restricted hospital set-up? J Pediatr Orthop B. 2013;22:101-5. https://doi.org/ 10.1097/BPB.0b013e32835c2a33

59. Caglar O, Aksoy MC, Yazici M, Surat A. Comparison of compression plate and flexible intramedullary nail fixation in pediatric femoral shaft fractures. J Pediatr Orthop B. 2006;15: 210-4. https://doi.org/ 10.1097/01.bpb.0000186642.91944.68

60. Hedin H, Hjorth K, Rehnberg L, Larsson S. External fixation of displaced femoral shaft fractures in children: a consecutive study of 98 fractures. J Orthop Trauma. 2003;17:250-6. https:// doi.org/ 10.1097/00005131-200304000-00002

61. Sela Y, Hershkovich O, Sher-Lurie N, Schindler A, Givon U. Pediatric femoral shaft fractures: treatment strategies according to age -13 years of experience in one medical center. J Orthopaed Surg Res. 2013;8:23. https://doi.org/ 10.1186/1749799X-8-23

62. Song H, Oh W, Shin D, Kim J, Kyung S, Baek H. Treatment of femoral shaft fractures in young children: comparison between conservative treatment and retrograde flexible nailing. J Pediatr Orthopaed B. 2004;4:275-80. https://doi.org/ 10.1097/01. bpb.0000111023.13276.43 
Sažetak

\title{
LIJEČENJE PRIJELOMA BEDRENE KOSTI KOD DJECE U GRADU ZAGREBU
}

\author{
A. Antabak, N. Boršćak, M. Čagalj, R. Ivelj, I. Bumči, D. Papeš, S. Ćavar, M. Bogović, K. Bulić i T. Luetić
}

Prijelomi bedrene kosti u djece mogu se liječiti operativno ili konzervativno. Više čimbenika utječe na izbor najbolje metode liječenja ovisno o vrsti prijeloma. Cilj ovoga istraživanja bio je utvrditi učestalost prijeloma bedrene kosti u djece na području Grada Zagreba i Zagrebačke županije i raspodjelu učestalosti prema mjestu nastanka, dobi djeteta te vrsti, načinu nastanka i načinu liječenja prijeloma. Istraživanje je uključilo 103 djece u dobi do 18 godina liječene zbog prijeloma bedrene kosti u Kliničkom bolničkom centru Zagreb i Klinici za dječje bolesti Zagreb. Podaci za ovu retrospektivnu analizu su prikupljeni iz navedenih ustanova za razdoblje od 2010. do 2015. godine. Uzroci nastanka prijeloma su šifrirani prema Međunarodnoj klasifikaciji bolesti. Kirurško liječenje je bilo potrebno u 55\% bolesnika, što nije u skladu s podacima iz prethodnih analiza. Najveća učestalost prijeloma bedrene kosti bila je u dobnoj skupini od 0 do 4 godine, koja čini $49,1 \%$ svih bolesnika. U toj skupini su prijelomi najčešće nastali prilikom pada i većinom su liječeni konzervativno. U svim ostalim dobnim skupinama prevladavalo je operativno liječenje. Najčešće primijenjeni konzervativni način liječenja je bila kokso-femoralna imobilizacija, a najčešći operativni način stabilna elastična osteosinteza titanskim čavlima. Način liječenja je ovisio o dobi, vrsti i složenosti prijeloma, pomaku ulomaka i udruženim ozljedama. Uzrok nastanka prijeloma je također bio važan čimbenik u odabiru načina liječenja. Konzervativno liječenje je većinom primijenjeno kod prijeloma koji su nastali padom (u 64,7\% prijeloma nastalih padom), a operativno liječenje većinom kod prijeloma nastalih u prometnim nezgodama (79,4\% tako nastalih prijeloma je liječeno operativno). Opće prihvaćeno je stajalište da je konzervativno liječenje najbolje za dijete. Ipak, u novijim radovima je povećana učestalost operativnog liječenja prijeloma bedrene kosti u djece. U našoj skupini bolesnika liječenih u razdoblju od 2010. do 2015. godine operativno liječenje također je bilo češće nego konzervativno. Primijenjena su dva načina konzervativnog liječenja i osam načina operativnog liječenja. Tako velik broj različitih načina liječenja pokazuje da ne postoji jedinstvena metoda za liječenje svih prijeloma. S druge strane, porast učestalosti operativnog liječenja je očito posljedica trajnih socio-demografskih i socio-ekonomkih promjena u urbanim područjima poput Zagreba. Promjena načina života izravno utječe na učestalost prijeloma bedrene kosti, kao i na način njihovog liječenja. Mišljenje većine je da se prijelomi nastali u ranoj dobi uglavnom mogu liječiti konzervativno. Naše istraživanje to potvrđuje: $75 \%$ bolesnika u najmlađoj dobnoj skupini, koji su činili većinu ozljeđenika $(49,1 \%)$, liječeni su konzervativno. Operativno liječenje je prevladavalo u drugim dobnim skupinama, a drugi autori su objavili slične rezultate. Zaključno, najmlađi bolesnici (u dobi od 0 do 4 godine) čine gotovo polovicu $(49,1 \%)$ svih bolesnika s prijelomom bedrene kosti. Najčešće mjesto prijeloma je bila dijafiza. Većina prijeloma u razdoblju od 2010. do 2015. godine liječena je operativno, većinom u djece u dobi od 5 do 9 godina. Od osam različitih operativnih načina liječenja, stabilna elastična osteosinteza bila je najčešća (60\%). Kokso-femoralna imobilizacija ili trakcija bile su najčešći konzervativni načini liječenja.

Ključne riječi: Bedrena kost; Prijelom; Djeca; Liječenje 